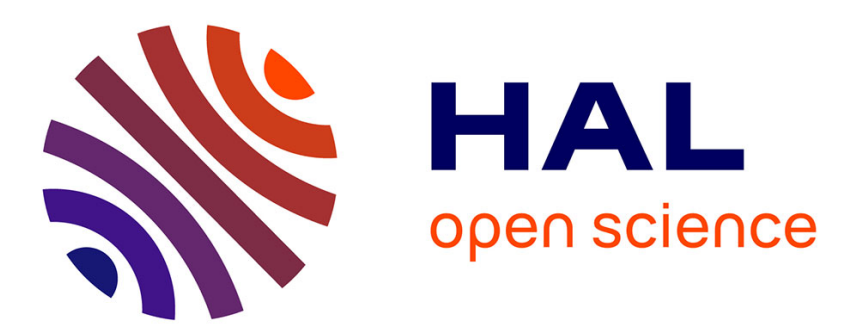

\title{
Climatological mean distribution of specific entropy in the oceans
}

\author{
Z. Gan, Y. Yan, Y. Qi
}

\section{To cite this version:}

Z. Gan, Y. Yan, Y. Qi. Climatological mean distribution of specific entropy in the oceans. Ocean Science Discussions, 2007, 4 (1), pp.129-144. hal-00298462

\section{HAL Id: hal-00298462 \\ https://hal.science/hal-00298462}

Submitted on 31 Jan 2007

HAL is a multi-disciplinary open access archive for the deposit and dissemination of scientific research documents, whether they are published or not. The documents may come from teaching and research institutions in France or abroad, or from public or private research centers.
L'archive ouverte pluridisciplinaire HAL, est destinée au dépôt et à la diffusion de documents scientifiques de niveau recherche, publiés ou non, émanant des établissements d'enseignement et de recherche français ou étrangers, des laboratoires publics ou privés. 
Ocean Sci. Discuss., 4, 129-144, 2007 www.ocean-sci-discuss.net/4/129/2007/ (C) Author(s) 2007. This work is licensed under a Creative Commons License.

\section{OSD}

4, 129-144, 2007

Distribution of entropy in the oceans

Y. Yan et al.

\section{Climatological mean distribution of specific entropy in the oceans}

Z. Gan, Y. Yan, and Y. Qi

LED, South China Sea Institute of Oceanology, Chinese Academy of Sciences, Guangzhou, China

Received: 5 December 2006 - Accepted: 24 January 2007 - Published: 31 January 2007

Correspondence to: Y. Yan (youfangyan@scsio.ac.cn)

\section{Title Page}

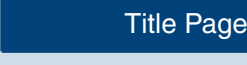

Abstract Introduction

Conclusions References

Tables

Figures

14

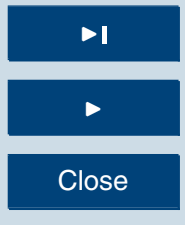

Full Screen / Esc

Printer-friendly Version

Interactive Discussion 


\section{Abstract}

Entropy as an important state function can be considered to provide insight into the thermodynamic properties of seawater. In this paper, the spatial-temporal distribution of specific entropy in the oceans is presented, using a new Gibbs thermodynamic po5 tential function of seawater, which is proposed by R. Feistel. An important result is found that the distribution of specific entropy is surprisingly different from that of potential density or neutral density surfaces. By contrast, the distribution of specific entropy is quite similar to that of potential temperature in the oceans. This result is not consistent with the traditional assumption that isopycnal or isoneutral surfaces could be approximately regarded as isentropic surfaces in the physical oceanography.

\section{Introduction}

Entropy, as enthalpy, internal energy of seawater is scientifically interesting thermodynamic state function of seawater. The concept of entropy and particularly the rate of entropy production form the central core of thermodynamic theory since entropy is 15 a measure for the amount of "disorder" or "chaos" in a system (Feistel and Ebeling, 1989). For a macroscopic system, the higher the entropy, the more disordered the system is. Conversely, the lower the entropy, the higher organized (ordered) the system is. In order to assess the entropy per unit mass, namely the specific entropy in the ocean, Fofonoff tried to derive entropy expression for the determination of the oceanic specific entropy. However, accuracy of entropy expression is difficult to establish in view of inadequate knowledge of the complex thermodynamic nature of seawater. As a result, the empirical formula of entropy is only known up to a linear function of salinity at that time (Fofonoff, 1962; Monin, 1973; Fofonoff and Millard, 1983). Recently, the relative specific free enthalpy (also called Gibbs function) of seawater, has been recomputed, which offers a very accurate, compact and consistent way for easy computation of specific entropy and other thermodynamical properties of seawater (Feistel, 2005).

\section{OSD}

4, 129-144, 2007

Distribution of entropy in the oceans

Y. Yan et al.

Title Page

Abstract Introduction

Conclusions References

Tables Figures

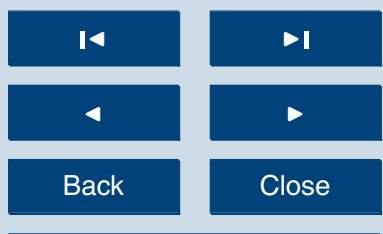

Full Screen / Esc

Printer-friendly Version

Interactive Discussion 
The purpose of this paper is to estimate the specific entropy distribution of seawater by using the accurate entropy expression in a manner that give a heuristic discussion of the differences between specific entropy, potential temperature and potential density in the ocean. The paper is organized as: in Sect. 2, the specific entropy formulas of 5 seawater are given in detail. The data used are given in Sect. 3. The distribution of specific entropy and the relationship between specific entropy, potential density and potential temperature is discussed in Sect. 4 and Sect. 5. Some conclusions are given in the Sect. 6.

\section{Entropy formula of seawater}

10 Numerical implementation of the Gibbs thermodynamic potential of seawater offers a very compact and consistent way of representing other thermodynamic properties such as entropy, potential temperature and potential density of seawater. The "relative" "specific" Gibbs function $G(S, t, p)$ as a function of the independent variables salinity, temperature and applied pressure can be expressed as (Feistel, 2005)

$G(S, t, p)=1 \mathrm{~J} / \mathrm{kg} \cdot \sum_{j, k}\left\{g_{0 j k}+g_{1 j k} x^{2} \ln x+\sum_{i>1} g_{i j k} x^{i}\right\} y^{j} z^{k}$,

where $x=\sqrt{S / 40}, y=\frac{t}{40^{\circ} \mathrm{C}}, z=\frac{p}{100 \mathrm{MPa}}$ represent salinity $(S)$, temperature $(t)$ and pressure $(p)$ in dimensionless form, respectively. $g_{i j k}$, the coefficients of equation, its value can be refer to the paper of Feistel (2005). Here, the attribute "specific" means that $G(S, t, p)$ is computed for $1 \mathrm{~kg}$ seawater ( $1 \mathrm{~kg}$ solution) and divided by $1 \mathrm{~kg}$. "Relative" and at the triple point of pure water where all ions interactions are neglected (Wagner and Pruß, 2002).

\section{OSD}

4, 129-144, 2007

Distribution of entropy in the oceans

Y. Yan et al.

Title Page

Abstract Introduction

Conclusions References

Tables

Figures

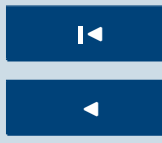

Back

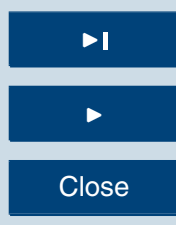

Full Screen / Esc

Printer-friendly Version

Interactive Discussion 
The specific entropy $(\eta)$, as one of the state functions of seawater can be computed by the derivatives of Gibbs function, namely

$\eta(S, t, p)=-\left(\frac{\partial G}{\partial t}\right)_{S, p}=-\frac{1 \mathrm{~J} \cdot \mathrm{kg}^{-1}}{40^{\circ} \mathrm{C}} \cdot \sum_{j, k}\left\{g_{0 j k}+g_{1 j k} x^{2} \ln x+\sum_{i>1} g_{i j k} x^{i}\right\} \cdot j \cdot y^{j-1} z^{k}$

Equation (2) is the specific entropy expression, which is valid for pressures from the 5 triple point to the critical point $100 \mathrm{MPa}$, for temperature from $-2^{\circ} \mathrm{C}$ to $-4^{\circ} \mathrm{C}$, for practical salinities up to $42 \mathrm{psu}$ and up to $50 \mathrm{psu}$ at normal pressure. Analogously to the Gibbs function, specific entropy is set to zero at the standard ocean state $(S=35 \mathrm{psu}$, $\left.t=0^{\circ} \mathrm{C}, p=0 \mathrm{~Pa}\right)$. For convenience, the relative, specific entropy is also called entropy or specific entropy except explicitly indicated in the following text.

\section{Data used}

The data used for the analysis of specific entropy are obtained from the World Ocean Atlas 2001 (WOA01), which contains the 1/4-degree grid climatological mean of temperature and salinity for the annual and monthly time periods (Conkright et al., 2002). The annual fields are calculated at standard levels from the surface to 5500 meters, 15 total 33 depths levels. The monthly fields are calculated at standard levels from the
surface to $1500 \mathrm{~m}$, total 24 depths levels. The 33 levels corresponding to the standard
depths are $0,10,20,30,50,75,100,125,150,200,250,300,400,500,600,700$, $800,900,1000,1100,1200,1300,1400,1500,1750,2000,2500,3000,3500,4000$, $4500,5000,5500 \mathrm{~m}$, respectively. The pressures are calculated from depth and latitude by using the generally accepted procedures from Processing of Oceanographic Station Data (JPOTS Editorial Panel, 1991). Besides, A16 transects data of World Ocean Circulation Experiment are used to estimate the profile distribution of specific entropy in the ocean (Data available at: http://whpo.ucsd.edu/data/co2clivar/atlantic/ a16/a16n_2003a/index.htm).

OSD

4, 129-144, 2007

Distribution of entropy in the oceans

Y. Yan et al.

\section{Title Page}

Abstract Introduction

Conclusions References

Tables Figures

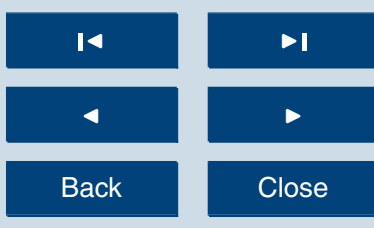

Full Screen / Esc

Printer-friendly Version

Interactive Discussion 


\section{Results and discussions}

\subsection{Horizontal distribution of the specific entropy in the ocean}

Specific entropy $\eta(S, t, p)$ defined by Eq. (2) as a function of $(S, t, p)$ is calculated by using the data of WOA01. Figure 1 shows the climatological annual mean global dis5 tribution of entropy at depths of $0 \mathrm{~m}, 500 \mathrm{~m}$ and $1500 \mathrm{~m}$. It is clear that the entropy of a shallower layer is higher than that of a deeper layer. That is to say, the higher entropy is always combined with low pressure over global oceans. In the case of the sea surface $(0 \mathrm{~m})$, the distribution of entropy tends to be zonal, that is, it is approximately independent of longitude. High entropy is seen near the equator, while low entropy occurs at polar latitudes. The deviations from zonal in the tropic domains are small. The largest zonal deviations occur in the center of ocean at about $40^{\circ}$ latitude in both hemispheres. The second entropy layer at depth of $500 \mathrm{~m}$ is selected to contour because it can illustrate the change of entropy between the variable surface and weakly stable but more uniform layer. In this layer, the significant feature is that the high entropy does not occur in the low-latitude domains but appear at mid-latitude especially on the western side of the ocean. At low latitudes, the entropy is relatively smaller and the entropy gradients along the meridional are also small. Different from the distribution of entropy at the sea surface and $500 \mathrm{~m}$ layers, the distribution of entropy at $1500 \mathrm{~m}$ depths is relatively uniform, just varying from $50 \sim 150 \mathrm{~J} /(\mathrm{kg} \cdot \mathrm{K})$, except some polar regions dominated by $p=0 \mathrm{~Pa})$

\subsection{Vertical structure of the specific entropy in the ocean}

To know about how the vertical structure of the specific entropy varies in the ocean, the entropy distribution in the Atlantic, Pacific and Indian Ocean profiles are shown in 25 Fig. 2. The longitude profiles distribution patterns of specific entropy on these three profiles are quite similar, though some relatively minor differences exist. For example,
OSD

4, 129-144, 2007

Distribution of entropy in the oceans

Y. Yan et al.

Title Page

Abstract Introduction

Conclusions References

Tables Figures

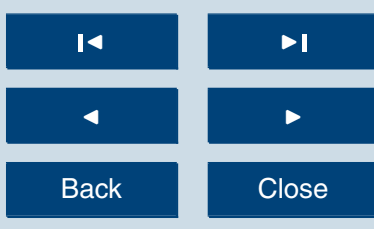

Full Screen / Esc

Printer-friendly Version

Interactive Discussion 
there is an obvious difference in the distribution pattern of specific entropy ranging from $100 \mathrm{~J} /(\mathrm{kg} \cdot \mathrm{K})$ to $400 \mathrm{~J} /(\mathrm{kg} \cdot \mathrm{K})$. In general, the variation of specific entropy with depth can be summarized as follows:

- A shallow "mixed" layer with high entropy exists over most of the ocean. Its thickness ranges from a few tens of meters up to a few hundreds of meters.

- A "sharp" change layer lies at the bottom of the mixed layer in which the entropy decreases rapidly with depth: rapidly at first, and then more gradually until it eventually levels off at $100 \mathrm{~J} /(\mathrm{kg} \cdot \mathrm{K})$.

- A deeper "uniform" layer where water retains its low entropy in the deep ocean. In addition, remarkable similarities between sea surface entropy at the southern polar region and the deep ocean are identified, which suggests that there is a very close link between sea surface water and bottom water in the global ocean.

\subsection{Seasonal variations of the sea surface entropy}

In order to gain a better feel for the specific entropy varies with the seasons, the entropy 15

of July minus January and that of October minus April at the sea surface are shown in Fig. 3. The largest absolute values of entropy are seen along the western coastal boundaries at mid-latitude oceans in the northern hemisphere, which comes to contact with the strong air-sea interaction. Relatively smaller values occur in the tropics, reaching as low as $50 \mathrm{~J} /(\mathrm{kg} \cdot \mathrm{K})$. Compared with the Northern hemisphere, the seasonal

\section{OSD}

4, 129-144, 2007

Distribution of entropy in the oceans

Y. Yan et al.

\section{Title Page}

Abstract Introduction

Conclusions References

Tables Figures

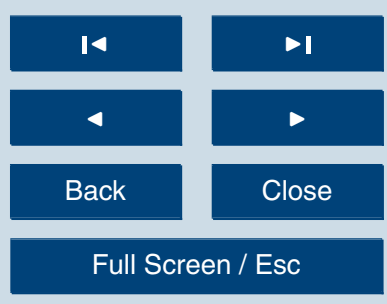

Printer-friendly Version

Interactive Discussion

Since processes that change its properties are week below the surface layer, ocean flow is much more likely to follow surfaces of constant entropy, or isentropic surfaces (Entropy is conserved if a process is adiabatic, that is has no change of heat or salt). 
Montgomery firstly introduced this concept in the 1930s. In the ocean, isentropic surfaces are difficult to determine because of the complicated empirical equation of state. Surfaces of constant potential density (isopycnals) referenced to a nearby pressure are a close approximation to isentropic surfaces (Montgomery, 1938). Surfaces of con5 stant neutral density (isoneutrals) have been argued to be almost identical to isentropic surfaces (McDougall, 1987). Therefore it has become common to map properties on isopycnal (or isoneutral or isentropic) surfaces (Pickard, 1990; Emery, 2006).

In performing the analysis on the above set of distributions of specific entropy, it is noted that the distribution of specific entropy is more closely linked to the well-known 10 distribution pattern of temperature in the ocean. In an effort to gain a straight contrast between specific entropy, potential density and potential temperature, the distributions of potential density and potential temperature at the sea surface, which are also calculated by using the Gibbs function are shown in Fig. 4. Returning to Fig. 1a, note that the differences between specific entropy and potential density on the sea surface appear obvious. In fact, the distribu

Another example of the difference between specific entropy, potential density and isoneutrals occurs when considering the distribution of the A16 transect in the Atlantic (Fig. 5). According to the common concept, the distribution of specific entropy of transect should be similar to that of potential density or isoneutrals since potential density surface or neutral surface is an approximation to isentropic surface. However, the physically relevant contrast of specific entropy potential density and neutral density implies that specific entropy and potential density or neutral density has not the similar pattern. By contrast, distribution pattern and scatter plot of potential temperature versus entropy indicate that there exists a well linear relationship between specific entropy and potential temperature in the ocean.

The contrast between specific entropy and potential density is even more pronounced in the $T-S$ plane (Fig. 6). Note that the potential density contours and entropy contours are not parallel. In contrast, they intersect with each other and should be

\section{OSD}

4, 129-144, 2007

\section{Distribution of entropy in the oceans}

Y. Yan et al.

\section{Title Page}
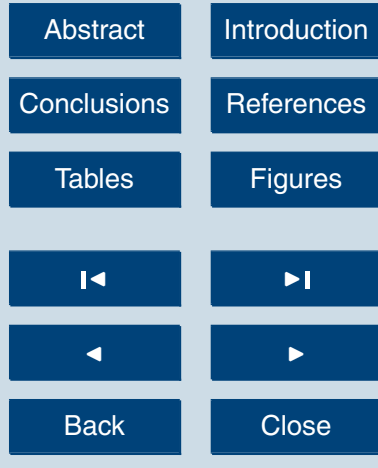

Full Screen / Esc

Printer-friendly Version

Interactive Discussion 
considered more approximately as a polynomial curve function. However, it is straightforward to show that the potential temperature contours is almost parallel to entropy contours. The reason for being not absolute parallel but almost parallel is that salinity also has a contribution to the specific entropy. To quantify the relationship between 5 specific entropy and potential temperature, a linear least square fitting is performed, and the result shows that there exists a highly correlated linear relationship between specific entropy and the natural logarithm of potential temperature

$\eta(S, t, p) \approx C_{0} \ln (\theta+273.15)+d$.

where $C_{0}=3950 \pm 5.3$ is approximate to the specific heat at the sea surface $C_{p_{0}}, \theta$ is on the temperature and salinity of seawater Interestingly, this relation is very similar to that of potential temperature and entropy in the atmosphere (Holton, 1992). In fact, this "empirical" relation can be deduced theoretically from thermodynamic relations, namely

${ }_{15} d \eta=C_{p 0} \frac{d \theta}{\theta}-\frac{\mu d S}{T}$.

The second term of Eq. (4) is the effect of salinity component. Assumed the effect of salinity can be neglected (see Fig. 6), the integration Eq. (4) is approximately equal to Eq. (3). The detail about the deduction will be reported in the other manuscript.

\section{Conclusions}

20 Because of the complex thermodynamic nature of seawater, exact calculation of entropy of seawater has been a long-standing knotty problem troubling oceanographers for a long time. A better understanding of the specific entropy distribution and its relation between potential density, neutral density and potential temperature of the global oceans is the aim of the present study. Based on a new and extended Gibbs function,
OSD

4, 129-144, 2007

Distribution of entropy in the oceans

Y. Yan et al.

Title Page

Abstract Introduction

Conclusions References

Tables

Figures

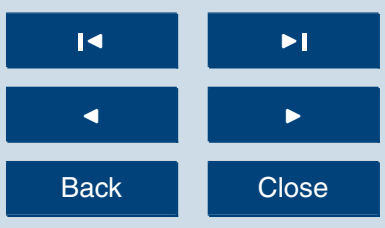

Full Screen / Esc

Printer-friendly Version

Interactive Discussion 
specific entropy in the ocean is calculated and the "World Ocean entropy atlas" is firstly presented. The resulting analysis reveals that the distributions of specific entropy are not similar to those of potential density or neutral density. This result is not consistent with the traditional assumption that isopycnal or isoneutral surfaces could be approxi5 mately treated as isentropic surfaces in the physical oceanography. In fact, isentropic surfaces are to a larger extent approximately equivalent to surfaces of constant potential temperature in the ocean.

Acknowledgements. We thank R. Feistel and R. X. Huang for correcting and giving many good suggestions and comments on the manuscript. Thanks are also given to the National Oceano10 graphic Data Center (NODC) and The CLIVAR and Carbon Hydrographic Data Office (CCHDO) for offering the data. This work was supported by the Chinese Academy of Sciences (Grant No. KZCX3-SW-227), the National Natural Science Foundation of China (Grant No. 40276004) and National Basic Research Program of China (Grant No. 2006CB403604).

\section{References}

15 Conkright, M. E., Locarnini, R. A., Garcia, H. E., O’Brien, T., Boyer, T., Stephens, C., and Antonov, J.: World ocean atlas 2001: Objective analyses, data statistics, and figures, CDROM documentation. National Oceanographic Data Center, Silver Spring, MD, 17 pp, 2002.

Feistel, R.: Numerical implementation and oceanographic application of the Gibbs thermodynamic potential of seawater, Ocean Sci., 1, 9-16, 2005,

20 http://www.ocean-sci.net/1/9/2005/.

Feistel, R. and Ebeling, W.: Evolution of Complex Systems. Kluwer Academic Publishers, Dordrecht /Boston/London, 1989.

Fofonoff, N. P.: Physical Properties of Seawater, in: The Sea, M.N.Hill Edition. Vol. 1, Physical Oceanography. Interscience, New York, 1962.

25 Fofonoff, N. P. and R. Millard C.: Algorithms for computation of fundamental properties of seawater, UNESCO Technical Papers in Marine Science, Vol. 44, UNESCO, 1983.

Holton, J. R.: An Introduction to Dynamic Meteorology (Third Edition) [M]. San Diego, California, USA: Academic Press, 1992.

JPOTS-Editorial-Panel: Processing of Oceanographic Station Data. Paris: UNESCO, 1991. 
McDougall, T. J.: Neutral surfaces, J. Phys. Oceanogr., 17, 1950-1964, 1987.

Monin, A. S.: On the hydrothermodynamics of ocean. Izvestiya, Atmos. Oceanic Phys., 9(10), 1063-1068, 1973.

Montgomery, R. B.: Circulation in upper layers of southern North Altantic deduced with use of OSD

5 isentropic analysis, Papers in Physical Oceanography and Meteorology, 6(2), 55, 1938.

Wagner, W. and Pruß A.: The IAPWS formulation 1995 for the thermodynamic propeties of ordinary water substance for general and scientific use, J. Phys. Chem. Ref. Data, 31, 387535, 2002.

Pickard, G. L. and Emery W. J.: Descriptive Physical Oceanography-An Introduction. 5th Edition. Pergamon Press, Oxford, 1990.

Emery, W. J., Talley L. D., and Pickard, G. L.: Descriptive Physical Oceanography, available at: HTU http://www-pord.ucsd.edu/ Italley/sio210/pickard_emery/UT.

4, 129-144, 2007

Distribution of entropy in the oceans

Y. Yan et al.

Title Page

Abstract

Introduction

Conclusions

References

Tables

Figures

14

$\rightarrow$

4

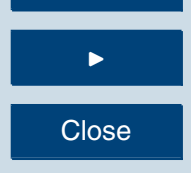

Back

Full Screen / Esc

Printer-friendly Version

Interactive Discussion

EGU 
(a). Specific entropy distribution at the sea surface $(0 \mathrm{~m})$

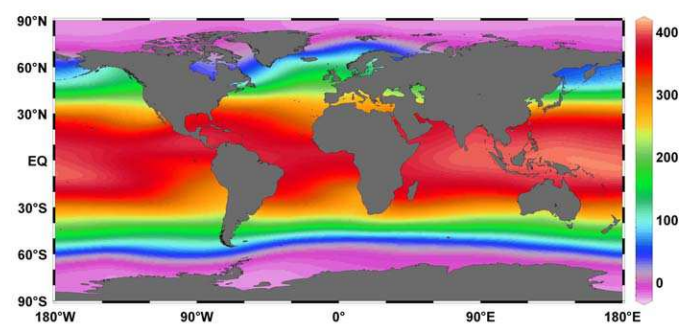

(b). Specific entropy distribution at the layer of $500 \mathrm{~m}$ depth

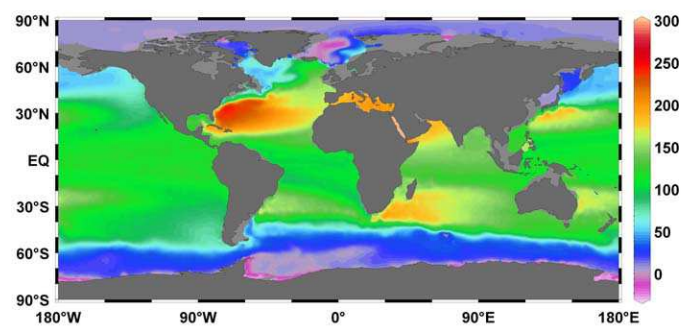

(c). Specific entropy distribution at the layer of $1500 \mathrm{~m}$ depth

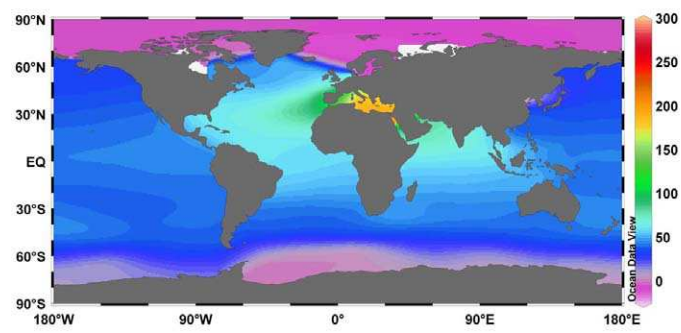

Fig. 1. Climatological annual mean specific entropy distribution at the surface of $0 \mathrm{~m}$ depth (a); $500 \mathrm{~m}$ depth (b) and $1500 \mathrm{~m}$ depth (c). The unit is $\mathrm{J} /(\mathrm{kg} \cdot \mathrm{K})$. Data used are obtained from the World Ocean Atlas 2001 (WOA01).
OSD

4, 129-144, 2007

Distribution of entropy in the oceans

Y. Yan et al.

\section{Title Page}

\section{Abstract}

Introduction

Conclusions

References

Tables

Figures

14

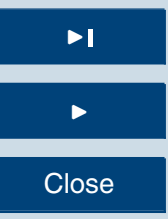

Full Screen / Esc

Printer-friendly Version

Interactive Discussion 


\section{OSD}

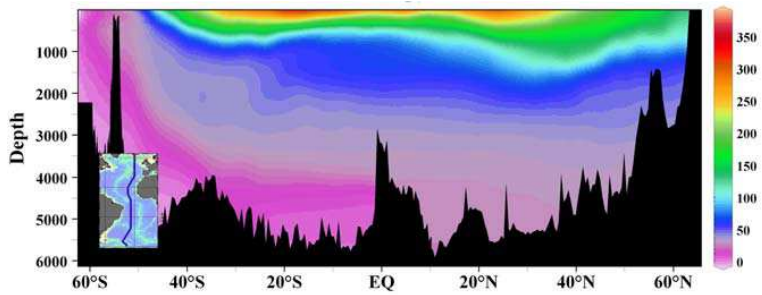

(b). Specific entropy versus depth through the Pacific Ocean

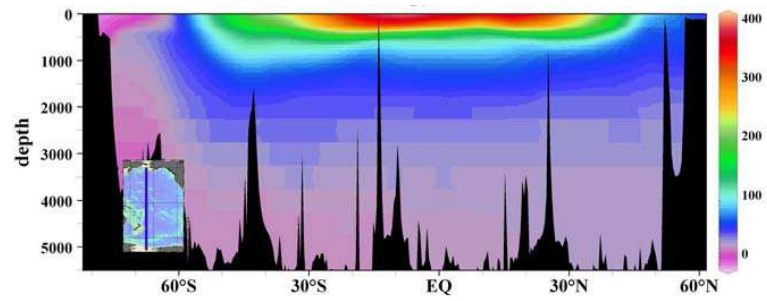

(c). Specific entropy versus depth through the Indian Ocean

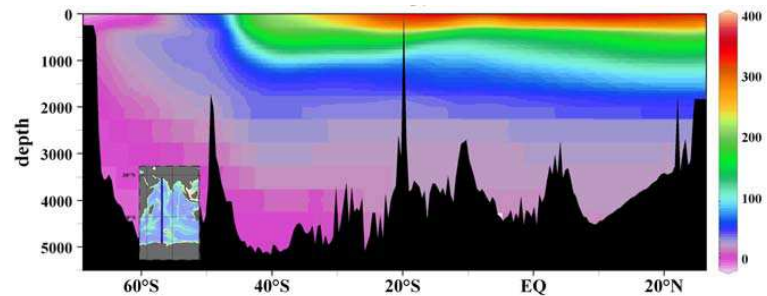

Fig. 2. Specific entropy versus depth through the Atlantic Ocean (a); Pacific Ocean (b); Indian Ocean (c) at the locations indicated by the inset. Data used are obtained from the World Ocean Atlas 2001 (WOA01).

Y. Yan et al.

\section{Title Page}

4, 129-144, 2007

Distribution of entropy in the oceans

\section{Abstract}

Conclusions

Tables

14

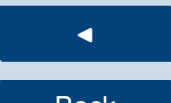

Back

Full Screen / Esc

Printer-friendly Version

Interactive Discussion
Introduction

References

Figures

$\rightarrow$

$>$

Close 
(a). Global distribution of entropy for January minus July

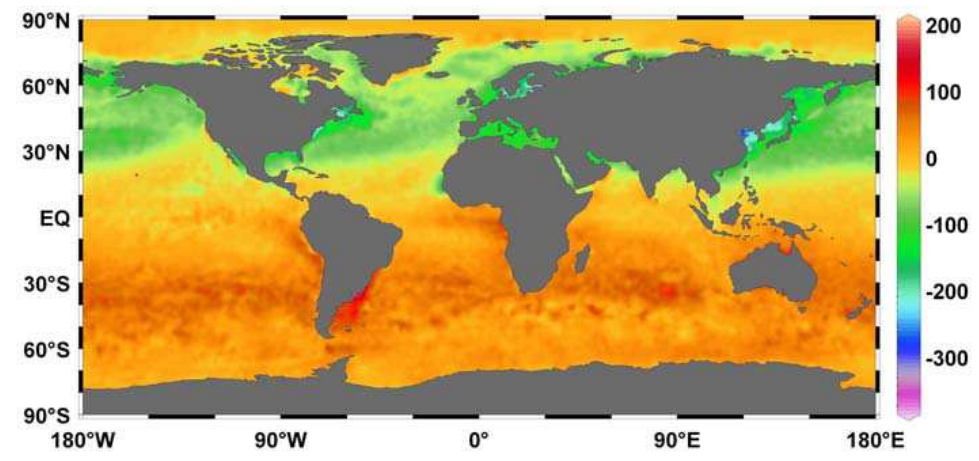

(b). Global distribution of entropy for October minus April

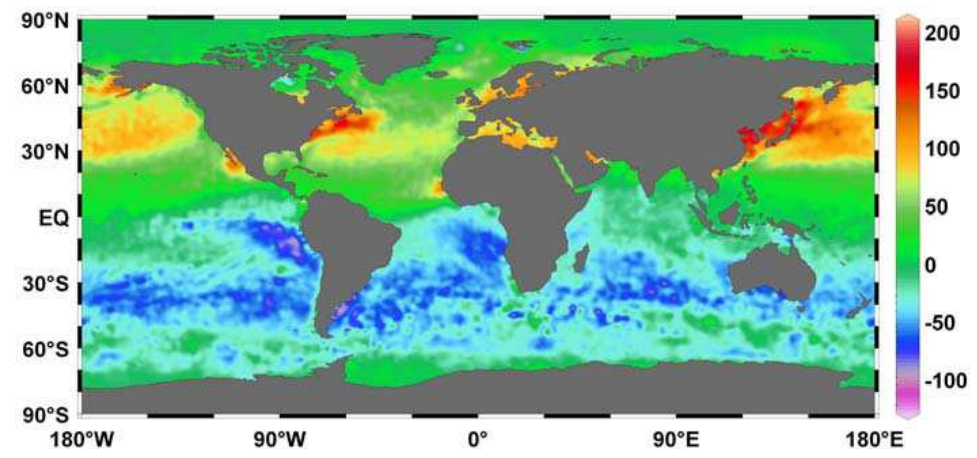

Fig. 3. Globally distributed estimates of entropy for January minus July (a); for October minus April (b) at the sea surface. The unit is $\mathrm{J} /(\mathrm{kg} \cdot \mathrm{K})$. Data used are obtained from the World Ocean Atlas 2001 (WOA01).

OSD

4, 129-144, 2007

Distribution of entropy in the oceans

Y. Yan et al.

Title Page

\section{Abstract}

Conclusions

Tables

14

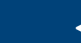

4

Back

Introduction

References

\section{Figures}

I

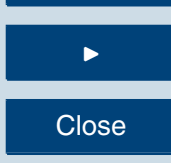

Full Screen / Esc

Printer-friendly Version

Interactive Discussion 
(a). Global distribution of potential density

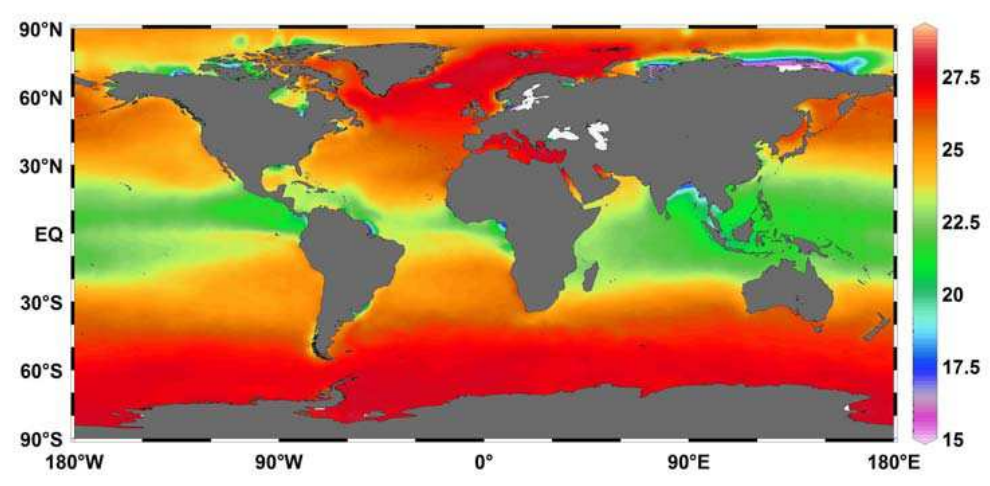

(b). Global distribution of potential temperature

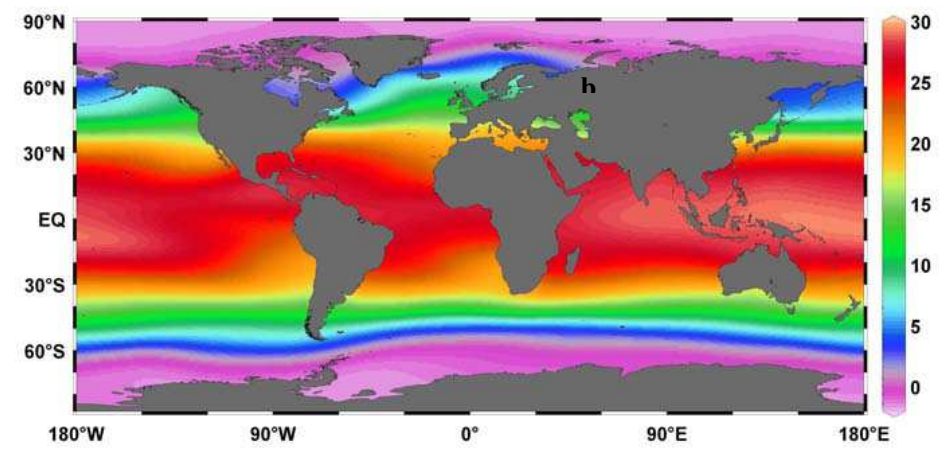

Fig. 4. Globally distributed estimates of potential density (a) and potential temperature (b) at the sea surface by using data of WOA01. It is very clear that entropy has a similar distribution pattern to that of potential temperature but not a similar pattern to that of potential density in the ocean. Data used are obtained from the World Ocean Atlas 2001 (WOA01).
OSD

4, 129-144, 2007

Distribution of entropy in the oceans

Y. Yan et al.

\section{Title Page}

\section{Abstract}

Introduction

Conclusions

References

Tables

Figures

14

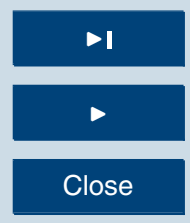

Back

Full Screen / Esc

Printer-friendly Version

Interactive Discussion 

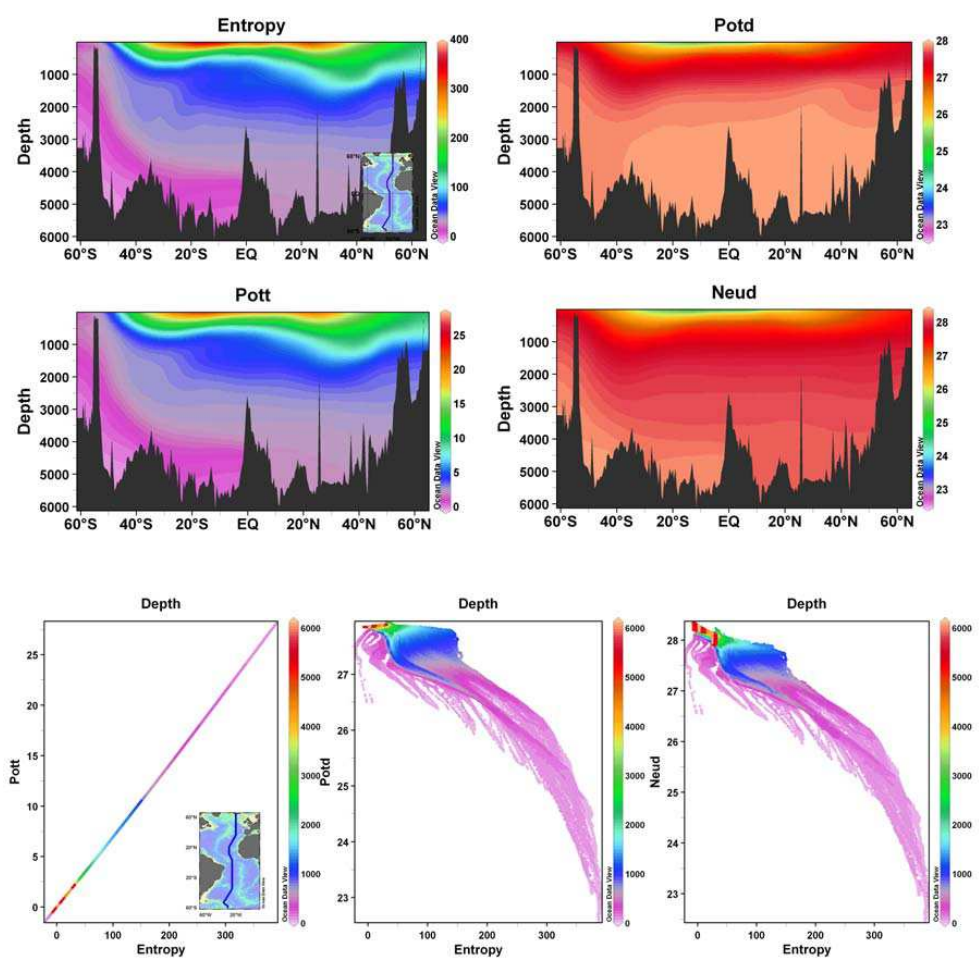

Fig. 5. The entropy (entropy), potential density (Potd), potential temperature (Pott) and neutral density (Neud), distribution; the scatter plots of entropy versus potential density, entropy versus neutral density and entropy versus potential temperature along a meridional section through the Atlantic Ocean by using the data of World Ocean Circulation Experiment (WOCE) A16 section. Obviously, there is not a good linear relationship between entropy and potential density or entropy and neutral density, whereas potential temperature can be treated as a linear function of entropy in the ocean. This result is not consistent with the commonly accepted assumption that an isentropic surface can be treated approximately as an isopycnal or isoneutral surface in the ocean.
OSD

4, 129-144, 2007

Distribution of entropy in the oceans

Y. Yan et al.

\section{Title Page}

\section{Abstract}

Introduction

Conclusions

References

Tables

Figures

14

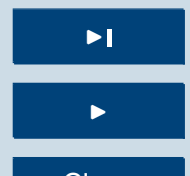

Back

Close

Full Screen / Esc

Printer-friendly Version

Interactive Discussion 
OSD

4, 129-144, 2007

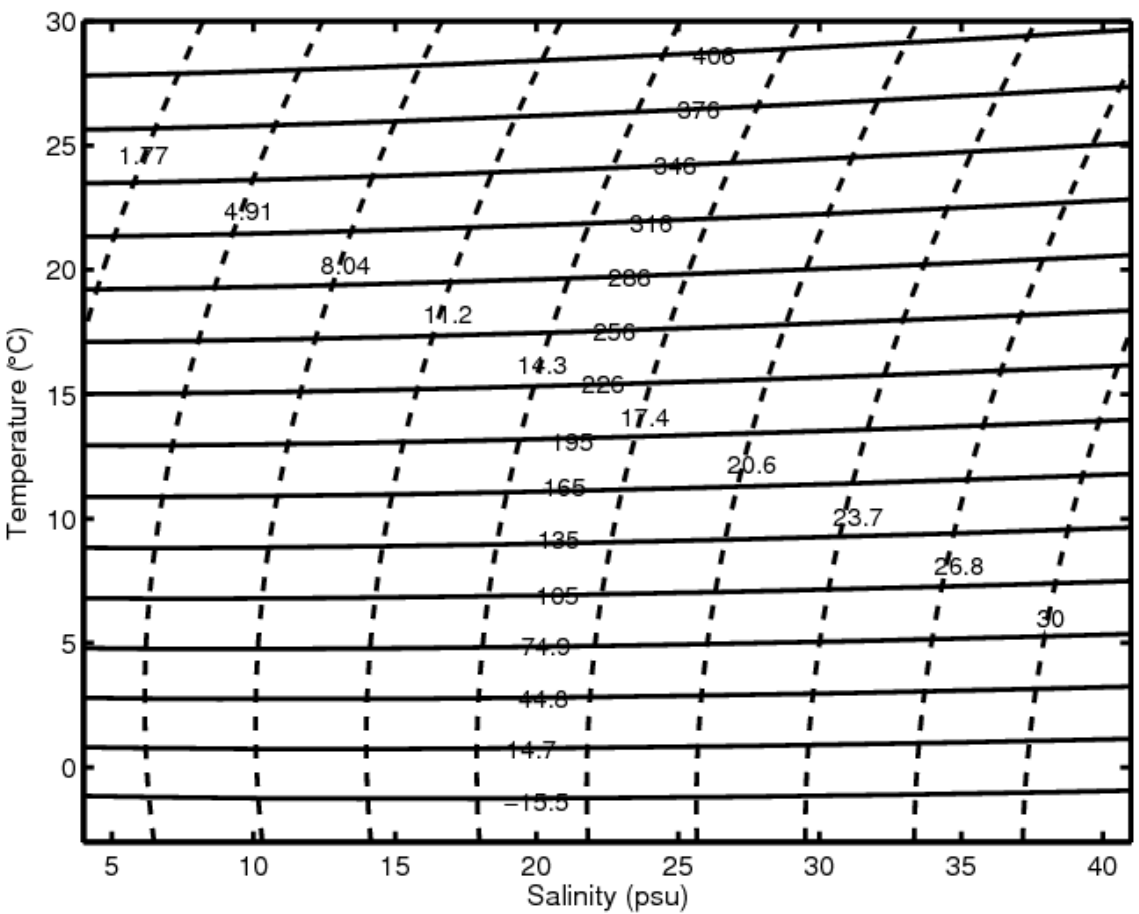

Distribution of entropy in the oceans

Y. Yan et al.

\section{Title Page}

Abstract

Introduction

Conclusions

References

Tables

Figures

14

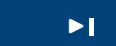

4

Back

Close

Full Screen / Esc

Printer-friendly Version

Interactive Discussion

EGU 